ESJ Natural/Life/Medical Sciences

\title{
Detection Of Fecal Coliforms In Water Used In Formal And Informal Food Outlets In Kasungu District, Malawi
}

\author{
Elton Chavura, MSc \\ University of Livingstonia, Department of Public health \\ F. Kapute, Prof. \\ Mzuzu University, Faculty of Environmental Science \\ Balwani Chingatichifwe Mbakaya, PhD \\ University of Livingstonia, Department of Public health
}

Doi:10.19044/esj.2021.v17n3p300

Submitted: 19 October 2020

Accepted: 15 January 2021

Published: 31 January2021
Copyright 2021 Author(s)

Under Creative Commons BY-NC-ND

4.0 OPEN ACCESS

Cite As:

Chavura E., Kapute F. \& Mbakaya B.C. (2021). Detection of fecal coliforms in water used in formal and informal food outlets in Kasungu District, Malawi. European Scientific Journal, ESJ, 17(3), 300.

https://doi.org/10.19044/esj.2021.v17n3p300

Abstract

Poor sanitary practices are common amongst many food handlers posing a health risk to consumers. Maintenance of high quality water is one of the most important aspects of ensuring consumer safety. Therefore, regular water testing is critical in public food outlets where bacterial contamination may cause outbreak of disease.

The study aimed at analyzing water samples obtained from the formal and informal food outlets for the presence of fecal coliforms that are indicative of poor sanitation that result in foodborne infections amongst consumers.

Using a cross-sectional design, water samples from participating food outlets $(\mathrm{N}=40)$ were analyzed using the membrane filtration method. Samples were filtered, under vacuum, through a cellulose acetate membrane of $0.45 \mu \mathrm{m}$ pore size.

Fecal coliforms exceeding permissible range were detected in 15 test samples $(\mathrm{N}=40)$. The median (IQR) concentrations of fecal coliforms (FC/100ml) in dishwashing water was 1(136) and 145(340) for the formal and informal food outlets respectively. The median (IQR) for drinking water was $0(0)$ with a minimum and maximum range of 0 and $14 \mathrm{FC} / 100 \mathrm{mls}$. 
The study established a positive correlation between fecal coliforms and electrical conductivity, and total dissolved solids $(\mathrm{p}<0.05)$ in dish washing water used at both formal and informal food outlets. Contamination was attributed to lack of running water, poor pest control and unwholesome practices in many food outlets.

Based on the study findings, it is concluded that electrical conductivity, total dissolved solids and turbidity values may be used to deduce the presence of fecal coliforms in water. The study recommends that water drawn from unprotected sources must be boiled or treated at the point of use before it can be safely used in food outlets. Periodic water testing and sanitary supervisions for all food outlets must be mandatory to ensure compliance with minimum set standards.

Key Words: Fecal Coliforms, Formal Food Outlets, Informal Food Outlets

\section{Introduction}

Drinking non-potable water predisposes people to waterborne disease outbreaks and unprecedented deaths (Prabhu \& Shar, 2012) yet in many instances, the opinion of water is subjected to its quantity rather than quality (Neswiswi, 2014). The risks associated with consumption of contaminated water is because of failure in securing optimal hygiene management practices at both formal and informal settings. Water quality encompasses physical, chemical and biological properties that are supposed to be in line with the required specifications (Agensi et al., 2019).

Coliform bacteria are facultatively anaerobic rod-shaped Gramnegative non-spore forming bacteria. They are mostly used as a measure of the sanitary quality of water (Leclerc, 2001). They are capable of fermenting lactose to produce acid and gas when incubated at a temperature range of between $35-37^{\circ} \mathrm{C}$ (Gruber, 2014). Coliform bacteria are found in large quantities in human excreta. Their presence is suggestive of other infective pathogens of fecal origin such as E. coli (Bandekar et al., 2006; Nwachukwu and Otokunefor, 2006). Besides traditional methods of detecting coliform bacteria, water quality factors have also been used as significant predictors of fecal coliform bacteria (Seo et al., 2019; Hayashi, 2004).

In many middle and low-income countries, cases of microbial contamination of water are linked to unwholesome practices, lack of water treatment at the point of use and unhygienic management of water sources (Agensi et al., 2019).

\section{Policy Framework}

Drinking water regulations involve the monitoring of bacterial, parasitic and chemical impurities that can endanger lives of consumers (Lee 
and Kim, 2002). To this end, with good water laws and policies in place, the expectation is provision of safe and potable water to uplift the health of people.

By description, formal food outlets are duly licensed facilities that remit tax to the government. In return, they enjoy access to public services such as piped water connections and waste collection services. Informal food outlets operate from unlicensed premises. They are unregistered, unregulated and unable to access institutional support (Jongh, 2015). The sale of food from unauthorized places is a criminal offence according to the Malawi Local Government sanitation and market By-Laws of 2015 and the Malawi National Environmental policy (2010). The policy framework outlines key policy statements on environmental sanitation, water quality testing and procedures for the certification and auditing of food outlets.

In this study we aimed (1) to analyze the microbial quality of water used in formal and informal food outlets; (2) to establish correlation between fecal coliforms and determinants of water quality (Water $\mathrm{pH}$, Turbidity (T), Total Dissolved Solids (TDS) and Electrical Conductivity (E.C.); and (3) to compare the level of risk of faecal contamination between the water used at formal and informal food outlets.

\section{Materials and methods}

\section{Design, sample size and sampling technique}

The study employed a cross-sectional design, using observational methods. The Municipal Chief executive provided a list of forty (40) licensed food outlets. The investigators identified eighty-six (86) informal food operations within the same locality. Using a simple random sampling technique on each cluster (formal \& informal), ten (10) formal and ten (10) informal food outlets were selected. Two (2) sample types, namely dishwashing water and drinking water, were collected from the twenty (20) randomly selected food outlets making a total sample size of (forty) (40) from both formal and informal food outlets in the Municipality. The sample size justification was based on the water quality studies by WHO (2008), that recommend testing as a minimum, $30 \%$ of households or locations in small projects of less than 500 households. See Table 1 showing recommended sample sizes according to WHO, (2008).

Table 1. Recommended sample sizes for water projects

\begin{tabular}{|c|c|}
\hline Project size & Sample size \\
\hline 500 & $41-85$ \\
\hline 1,000 & $43-91$ \\
\hline 2,000 & $43-95$ \\
\hline 3,000 & $44-97$ \\
\hline $4,000-6,000$ & $44-98$ \\
\hline $7,000-15,000$ & $44-99$ \\
\hline
\end{tabular}




\begin{tabular}{|ll|l|}
\hline$>20,000$ & $44-100$ \\
\hline \multicolumn{3}{|c|}{ Source: WHO, (2008). } \\
\hline
\end{tabular}

\section{Study site}

The study was conducted in the municipality of Kasungu District in Central Malawi between April to July, 2019. The district has a population of 735,836 and is bordered by Zambia to the West, Mchinji district to the Southwest, Dowa and Lilongwe districts to the South, Ntchisi and Nkhotakota districts to the East, and Mzimba District to the North. (See Figure 1) Kasungu Manucipality is on grid reference 33o 30' east and 13o 03' south and about 127 kilometers North of Lilongwe, the capital city of Malawi. It is along the M1 Road running from Lilongwe to Mzuzu (Kasungu Urban socio-economic profile, 1998). The municipality is supplied with piped water by Central Region Water Board (CRWB).

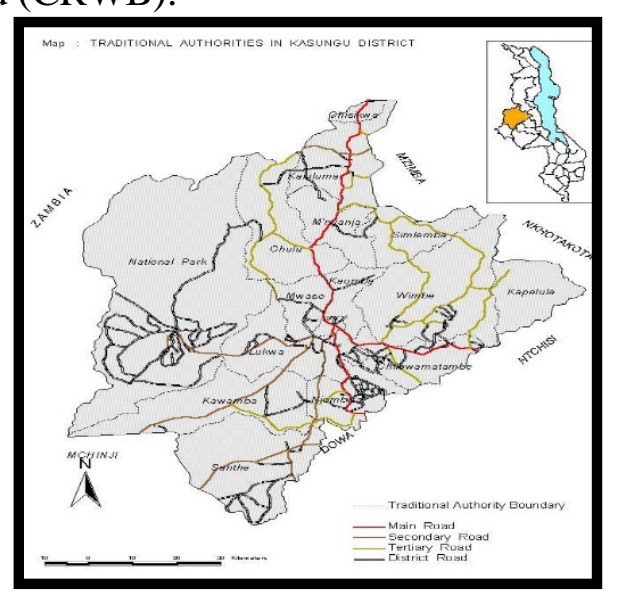

Figure 1. Map of Kasungu district (Source: Urban socio-economic profile, 1998)

\section{Ethics}

Ethical approval to conduct the study was obtained from National Council of Science and Technology (NCST), with approval number NCST/RTT/2/6. Clearance was obtained from the Chief Executive of Kasungu Municipal Council and food outlets managers. Written informed consent was obtained from food outlet managers in order to get permission to collect water samples and to inspect their premises.

\section{Data collection and study instruments}

Samples were collected by a public health graduate with expertise in water and sanitation. Samples for Measurement of $\mathrm{pH}$, Total dissolved solids, and Turbidity were tested on site using a lab Force TS- PH200 portable pH meter, a digital TDS tester meter electrode (HM Digital TDS-4), and a batteryoperated digital turbidity meter (model number WGZ- 20) respectively. For 
thermo tolerant (faecal) coliforms, samples were transported on ice in a cooler box at a temperature below $10^{\circ} \mathrm{C}$ to CRWB lab in Kasungu within 30 minutes from the last sample collection point. Samples were incubated at $44.5^{\circ} \mathrm{C}$ for 24 hours using a portable Millipore bacterial incubator.

The following checklist and observational methods were used to collect data:

\section{Sanitary inspection and risk score for the food premises}

Intrinsic bias was eliminated by the application of two data collection methods (sanitary inspection and sample testing) to facilitate reliability and validity. Sanitary inspection was done in order to identify the possible sources of faecal contamination.

The sanitary inspection checklist was designed based on standards and guidelines drawn by city/ municipal councils, The Malawi Bureau of Standards (MBS), Malawi National Environmental Health, and Sanitation policy. This checklist was used to inspect water storage areas, assess employee hygiene, as well as facility design. The sanitary checklist had 10 hazard statements designed to capture the most likely sources of water contamination such as availability of running water, pest control, use of protective wear/ uniforms etc. See Table 2 below:

Table 2. The sanitary inspection tool for the food outlets

\begin{tabular}{|c|c|c|c|c|c|}
\hline \multirow{2}{*}{ Hazard } & Formal & \multicolumn{2}{|c|}{ Informal } \\
\cline { 2 - 6 } & Yes & No & Yes & $\begin{array}{c}\text { N } \\
0\end{array}$ \\
\hline 1 & 9 & 1 & 0 & 10 \\
\hline 2 & $\begin{array}{c}\text { Is the quantity of water that you receive from your main source of } \\
\text { water adequate? }\end{array}$ & 9 & 1 & 0 & 10 \\
\hline 3 & Is water reserved for drinking safely covered?(tight lid cover) & 8 & 2 & 6 & 4 \\
\hline 4 & 9 & 1 & 3 & 7 \\
\hline 5 & $\begin{array}{c}\text { As the water treated at source point? } \\
\text { kitchen and emptieds regularly? }\end{array}$ & 8 & 2 & 0 & 10 \\
\hline 6 & Is staff trained in basic food hygiene practices? & 3 & 7 & 0 & 10 \\
\hline 7 & $\begin{array}{c}\text { Are food handlers provided with uniforms, caps, aprons and hair } \\
\text { nets? }\end{array}$ & 5 & 5 & 0 & 10 \\
\hline 8 & $\begin{array}{c}\text { Is jewelry limited to a plain ring, such as a wedding band, and no } \\
\text { bracelets? }\end{array}$ & 6 & 4 & 4 & 6 \\
\hline 9 & $\begin{array}{c}\text { Is there a procedure for referring sick employees for a prompt } \\
\text { medical opinion on fitness for work? }\end{array}$ & 2 & 8 & 0 & 10 \\
\hline 10 & $\begin{array}{c}\text { Are kitchen storage areas regularly checked for pest infestations } \\
\text { (mice, insects, etc.)? }\end{array}$ & 2 & 8 & 0 & 10 \\
\hline Total & 61 & 39 & 13 & 87 \\
\hline
\end{tabular}

\section{Field testing procedure}

Using a membrane filtration method, a volume of $100 \mathrm{mls}$ of water sample was filtered, under vacuum, through a cellulose acetate membrane of $0.45 \mu \mathrm{m}$ pore size. The sampling bottles were labeled with sample reference 
number, site, date and time and were incubated for 24 hours at a temperature of $44.5^{\circ} \mathrm{C}$.

\section{Data analysis}

Data was collected using a checklist and entered into an excel sheet, cleaned and sorted. Thereafter, Statistical Package for Social Sciences (SPSS) version 20 was used to analyze the data. For descriptive statistics, the Median with an associated Interquartile Range (IQR) was used and the Wilcoxon Rank Sum statistical test was employed to determine systematic differences in the risk of faecal coliform contamination between formal and informal food outlets and the level of contamination between drinking water and dishwashing water. The relationship between faecal coliforms and other determinants of water quality were compared using Spearmans Rho because

\begin{tabular}{l|ccc|ccc|ccc|ccc}
\hline & \multicolumn{5}{|c|}{ Drinking Water } & \multicolumn{5}{c}{ Dish Washing } \\
\hline & \multicolumn{3}{|c|}{ Formal } & \multicolumn{3}{c|}{ Informal } & \multicolumn{3}{c|}{ Formal } & \multicolumn{3}{c}{ Informal } \\
\hline Parameter & Median(IQR) & Min & Max & Median(IQR) Min & Max & Median(IQR) & Min & Max & Median(IQR) & Min & Max \\
\hline FC/100mls & $0(0)$ & 0 & 14 & $0(0)$ & 0 & 96 & $1(136)$ & 0 & 450 & $145(340)$ & 0 & 680 \\
pH & $7.6(0.18)$ & 7.46 & 7.8 & $7.7(0.11)$ & 7.58 & 7.93 & $7.62(0.22)$ & 6.94 & 7.93 & $7.66(0.26)$ & 7.01 & 7.89 \\
EC & $175(2)$ & 167 & 181 & $178.5(5)$ & 163 & 182 & $178(6)$ & 76 & 1094 & $182(7)$ & 177 & 991 \\
TDS & $104.5(2)$ & 100 & 107 & $107.5(3)$ & 98 & 109 & $107(4)$ & 45 & 657 & $109.5(4)$ & 106 & 598 \\
T & $1.6(0.72)$ & 0.68 & 135 & $1.88(1.23)$ & 0.59 & 6.78 & $1.42(2.22)$ & 0.59 & 8.58 & $4.95(12.56)$ & 1.98 & 460 \\
\hline
\end{tabular}

available data was not normally distributed. We used a checklist for sanitary inspection to ascertain possible sources of water contamination at food outlets.

\section{Results}

Water quality refers to the chemical, physical, biological and radiological characteristics of water relative to the requirements of any human need. Water is a critical raw material in many food establishments; and contaminated water can become a public health risk when it is used for activities such as drinking, washing of foods, incorporated as a food ingredient, or for washing utensils and hands. All food outlets (formal and informal) used piped water as their primary source of drinking water. However, when piped water could not be accessed, people drew water from alternative sources within their reach. Water quality testing gave us a snapshot of the quality of water that was found in use at the time of the study.

\section{A summary of the questions in the checklist is tabulated as in Table 6}

Objective 1: In this study, we aimed to analyze the quality of water used in formal and informal food outlets. The following is the results table (Table 3).

Table 3: Analysis of water quality parameters 
To establish strength of association between fecal coliforms and determinants of water quality (Water $\mathrm{pH}$, Turbidity (T), Total Dissolved Solids (TDS) and Electrical Conductivity (E.C.); the results table 4 below shows a positive correlation between FC and other determinants of water quality.

Objective 2: To establish correlation between fecal coliforms and determinants of water quality (Water $\mathrm{pH}$, Turbidity (T), Total Dissolved

\begin{tabular}{|c|c|c|c|c|c|c|c|c|c|c|c|c|c|c|c|c|c|c|}
\hline & \multicolumn{9}{|c|}{ Drinking Water } & \multicolumn{9}{|c|}{ Dishwashing Water } \\
\hline & \multicolumn{3}{|c|}{ formal } & \multicolumn{3}{|c|}{ Informal } & \multicolumn{3}{|c|}{ overall } & \multicolumn{3}{|c|}{ formal } & \multicolumn{3}{|c|}{ Informal } & \multicolumn{3}{|c|}{ overall } \\
\hline Param & $\bar{N}$ & Rho & P-val & $N$ & Rho & P-val & $N$ & Rho & P-val & $\bar{N}$ & Rho & P-val & $N$ & Rho & P-val & $N$ & Rho & P-val \\
\hline $\mathrm{PH}$ & 10 & 0.52 & 0.120 & 10 & 0.53 & 0.117 & 20 & 0.55 & 0.012 & 10 & .0 .23 & 0.530 & 10 & 0.23 & 0.516 & 20 & 0.05 & 0.811 \\
\hline$E C$ & 10 & 0.53 & 0.116 & 10 & -0.26 & 0.474 & 20 & 0.06 & 0.815 & 10 & 0.65 & 0.043 & 10 & 0.74 & 0.014 & 20 & 0.70 & $<0.001$ \\
\hline TDS & 10 & 0.47 & 0.168 & 10 & -0.21 & 0.558 & 20 & 0.02 & 0.934 & 10 & 0.76 & 0.011 & 10 & 0.77 & 0.001 & 20 & 0.76 & $<0.001$ \\
\hline $\mathrm{T}$ & 10 & 0.41 & 0.242 & 10 & -0.14 & 0.703 & 20 & 0.07 & 0.780 & 10 & 0.76 & 0.011 & 10 & 0.37 & 0.287 & 20 & 0.60 & 0.005 \\
\hline
\end{tabular}

Solids (TDS) and Electrical Conductivity (E.C.) using Spearman's correlation.

Table 4. Correlation between fecal coliforms and determinants of water quality

The study also sought to compare the level of risk of faecal contamination between the water used at formal and informal food outlets; and the extent to which drinking water differed with dishwashing water in terms of FC contamination. Basically, for both drinking water and dishwashing water, the sum of ranks for Informal outlets was higher than that of formal outlets but the difference was not statistically significant. See results Table 5.

Objective 3: To compare the level of risk of faecal contamination between the water used at formal and informal food outlets.

Table 5. A comparison table between formal and informal food outlets

\begin{tabular}{|c|c|c|c|c|c|c|}
\hline & \multicolumn{3}{|c|}{ Drinking Water } & \multicolumn{3}{|c|}{ Dishwashing Water } \\
\hline Classification & $\mathbf{N}$ & $\begin{array}{c}\text { Sum of } \\
\text { Ranks }\end{array}$ & P-value & N & $\begin{array}{c}\text { Sum of } \\
\text { Ranks }\end{array}$ & P-value \\
\hline Formal & 10 & 99 & \multirow{2}{*}{$0.466^{\mathrm{NS}}$} & 10 & 90 & \multirow{2}{*}{$0.241^{\mathrm{NS}}$} \\
\cline { 1 - 3 } & 10 & 111 & 10 & 120 & \\
\hline
\end{tabular}

- Method used: Mann-Whitney U test (Non Parametric test)

NS: Not statistically significant

\section{Discussion}

Water is an essential resource in food outlets. Using water of potable quality is the safest option in food outlets; however, access to exclusive potable water requirements may not always be feasible and practical due to intermittent supply outages of the commodity. This prompts food workers to 
fetch water from unprotected water sources thereby risking consumers to waterborne infections.

\section{Formal food outlets}

Using the sanitary inspection tool in figure 3, Formal food outlets enjoyed better sanitary services such as running water, and waste collection services by municipal authorities. However, food handlers working therein were not trained in basic food hygiene. There was no proper mechanism of handling sick food handlers and about when they would return to work after recovery. Their kitchens and storage areas were not regularly checked for pest control. This increased the risk of water contamination at these premises. Only one (1) single food outlet at the formal section served water to consumers that had a higher level of faecal coliforms of up to $14 \mathrm{FC} / 100 \mathrm{mls}$ that exceeded WHO (2008) and the MBS MS: 214 (2013) permissible range of 0 FC/100mls in any water intended for drinking (see Table 6). None compliance to expected standards can put the lives of consumers at risk. The median (IQR) for drinking water at this section was $0(0)$ with a minimum and maximum range of 0 and 14 FC/100mls.

For dishwashing water, the quality was severely compromised. High levels of faecal coliforms were detected in this type of water and at several outlets. Better sanitary services provided by the municipal council here did not translate into desired outcome as evidenced by the detection of large quantities of faecal coliforms with a median (IQR) of 1(136) and a minimum and maximum range of 0 and $450 \mathrm{FC} / 100 \mathrm{mls}$ respectively. These findings are consistent with Asogwa et al. (2015) and Marobhe and Sabai (2016) who detected high bacterial counts from dishwashing water that was used by food handlers as it was not regularly replaced with fresh water - a practice they attributed to lack of food hygiene training.

\section{Informal food outlets}

The informal food outlets operated without fulfilling minimum set standards. They lacked basic infrastructure and sanitary services thereby increasing the perception that water they served to consumers was potentially harmful to human health. The Malawi National Environmental Health Policy, (2010) advocates for improved water quality, sanitation, and hygiene at public and business institutions. Clause 5.4.1.3.2 of the Malawi Bureau of Standards (MBS) states non-potable water may be used with the acceptance of the MBS for steam production, firefighting, and other similar purposes not connected with food. See table 6 for drinking water standards

Table 6. Drinking Water Standards

\section{Parameter}

Normal value 


\begin{tabular}{|c|c|}
\hline Fecal coliforms & $0 \mathrm{FC} / 100 \mathrm{mls}$ \\
\hline $\mathrm{pH}$ & $6.5-8.5$ \\
\hline TDS & $\leq 500 \mathrm{mg} / \mathrm{l}$ \\
\hline $\mathrm{EC}$ & $\leq 400 \mu \mathrm{S} / \mathrm{cm}$ \\
\hline $\mathrm{T}$ & $<1 \mathrm{NTU}$ \\
\hline
\end{tabular}

Source: WHO, 2008

Drinking water sampled at the informal section was contaminated because of unwholesome food handling practices. Workers performed their duties entirely in their street clothes and lacked basic food hygiene education. Lack of running water ranked so high amongst all informal food outlets basing on the checklist on sanitary inspection. Besides this, the water they used was in insufficient quantities, which compromised hygiene standards. The median (IQR) for drinking water at this section was 0(0) with a minimum and maximum range of 0 and $96 \mathrm{FC} / 100 \mathrm{mls}$ respectively. Despite many challenges consistent with the informal food outlets, water for drinking was safely stored in containers with a lid cover.

As for dishwashing water, the informal section registered unprecedented FC count. The median (IQR) was as high as 145(340) with a minimum and maximum range of 0 and $680 \mathrm{FC} / 100 \mathrm{mls}$ respectively. The usage of such quality of water is unacceptable and demonstrates the highest level of deception and complete lack of integrity in food business which has been going on unchecked. A similar study (Musa and Akande, 2003) recommended strict measures in checking compliance to good hygiene practices amongst informal food handlers because their findings revealed unwholesome practices such as recycling of dirty water, lack of soap, and use of limited utensils. Multiple lines of evidence indicate that water is contaminated by pathogenic bacteria due to poor hygiene practices (Muzaffar et al., 2009; Hanashiro et al., 2005; Kruy et al., 2001) which expose many consumers to risk of waterborne diseases.

\section{Correlation of FC with other determinants of water quality}

A positive correlation was noted between FC and EC, TDS and T. $(p<0.05)$ in dish washing water used at both formal and informal food outlets. The findings are consistent with an earlier study (Busse and Hefeker, 2007) that confirmed a positive correlation between turbidity and faecal coliforms. Armah (2014) and Nura and Hamzaraj (2016) concluded that pH, electrical conductivity, total dissolved solids, and turbidity were significant predictors of total coliform bacteria in water. Although all other determinants of water quality are in agreement with the studies mentioned above, this study however, failed to prove the relationship between $\mathrm{pH}$ and FC. This could be attributed to a smaller sample size that was used. Considering the findings of this study, 
on the correlation between faecal coliforms and other determinants of water quality, it is concluded that EC, TDS and T values may be used to deduce the presence of faecal coliforms in water.

\section{Comparative analysis of the level of risk of fecal contamination}

The study also sought to compare the level of risk of faecal contamination between the water used at formal and informal food outlets; and the extent to which drinking water differed with dishwashing water in terms of FC contamination.

\section{Formal and informal food outlets}

Formal food outlets in this study failed to live up to consumer expectation. They demonstrated laxity in quality assurance for use of polluted water for cleaning dishes just as other counterparts in the informal section. This is despite having running water at their premises. Wilcoxon-MannWhitney $\mathrm{U}$ test $p$ - values of 0.466 and 0.241 between formal and informal food outlets respectively were statistically insignificant. We aimed to determine whether there is a difference in the risk of contamination between formal and informal outlets based on the median scores of drinking water as well as dishwashing water quality used at these types of food outlets. A 2010 U.S. Environmental Protection Agency (EPA) study found fecal contamination in nearly half of surveyed water dispensers in Virginia restaurants. In the city of Dhaka, a study (Faruk and Akhter, 2012) detected faecal coliforms in 84\% of water samples meant for consumers in restaurants and fast food shops.

\section{Limitations of the study}

The study focused on food outlets within the municipal central business market. Peripheral food outlets were not included in the study due to resource limitations as such, the sample size was smaller than previously desired which could trigger type 2 errors, thereby decreasing inference and the statistical power of the study. Secondly, potable water quality defined by levels of fecal coliforms alone is not enough for ascertainment of safe water use in food outlets as it is not considered an appropriate surrogate for the diversity of bacteria, viruses and parasites that may be present in water.

\section{Conclusion}

Findings of this study concluded there was evidence of fecal contamination of water used in the food outlets in the study area. Contaminated water was used for many activities such as dish washing, washing of food stuffs and served to consumers for drinking. Findings also showed that some determinants of water quality such as turbidity and total dissolved solids were so predictive of faecal contamination. Although formal food outlets had better sanitary conditions than the informal ones, the study 
did not establish any significant differences in terms of microbial quality. The study observed that poor microbial quality of water was in use in some food outlets in the informal section. The study recommends a robust sensitization campaign on the various methods of in-house water treatment to all food handlers. Under the same observation, the municipal town authority must conduct periodic ascertainment of water quality in food outlets as a strategy to improve the microbial quality. Based on the correlation findings between fecal coliforms and other determinants of water quality, it is concluded that EC, TDS and T values may be used to deduce the presence of faecal coliforms in water. The risk of contamination was the same regardless of type of food outlet. We therefore recommend that issuance and renewal of food business licensing must be effected subject to fulfilling minimum acceptable hygiene and food safety standards.

We propose that future studies (1) should consider bench-marking water at the very source point before the distribution terminal; (2) and a larger sample size to reduce the margin of error.

\section{Appendix}

Table 6. Water quality data for drinking and dish washing $(\mathrm{N}=40)$

\begin{tabular}{|c|c|c|c|c|c|c|c|c|c|c|}
\hline Sample & Source & \multicolumn{2}{|c|}{ Coordinates } & Sample type & Classification & FC/100mls & pH & EC & TDS & Turbidity \\
\hline 1 & s2 & 552820 & 8557230 & Drinking Water & Formal & 0 & 7.46 & 167 & 100 & 1.38 \\
\hline 2 & & & & $\begin{array}{l}\text { Dishwashing } \\
\text { water }\end{array}$ & & 220 & 7.93 & 177 & 107 & 3.24 \\
\hline 3 & s3 & 551914 & 8557614 & Drinking Water & Formal & 0 & 7.63 & 175 & 104 & 1.6 \\
\hline 4 & & & & $\begin{array}{c}\text { Dishwashing } \\
\text { Water }\end{array}$ & & 2 & 7.64 & 181 & 108 & 1.02 \\
\hline 5 & s4 & 551892 & 8557672 & Drinking water & Formal & 0 & 7.63 & 175 & 104 & 1.6 \\
\hline 6 & & & & $\begin{array}{c}\text { Dishwashing } \\
\text { Water }\end{array}$ & & 0 & 7.63 & 175 & 104 & 1.6 \\
\hline 7 & s5 & 552042 & 8557740 & Drinking Water & Formal & 0 & 7.68 & 178 & 107 & 1.58 \\
\hline 8 & & & & $\begin{array}{c}\text { Dishwashing } \\
\text { Water }\end{array}$ & & 0 & 7.76 & 174 & 104 & 1.36 \\
\hline 9 & s6 & 552047 & 8557750 & Drinking Water & Formal & 0 & 7.48 & 176 & 106 & 135 \\
\hline 10 & & & & $\begin{array}{c}\text { Dishwashing } \\
\text { Water }\end{array}$ & & 120 & 7.5 & 178 & 107 & 1.47 \\
\hline 11 & s7 & 552018 & 8558158 & Drinking Water & Formal & 0 & 7.56 & 173 & 104 & 1.2 \\
\hline 12 & & & & $\begin{array}{c}\text { Dishwashing } \\
\text { Water }\end{array}$ & & 0 & 7.47 & 178 & 107 & 1.26 \\
\hline 13 & s8 & 551999 & 8558198 & Drinking Water & Formal & 14 & 7.8 & 181 & 107 & 2.37 \\
\hline
\end{tabular}




\begin{tabular}{|c|c|c|c|c|c|c|c|c|c|c|}
\hline 14 & & & & $\begin{array}{c}\text { Dishwashing } \\
\text { Water }\end{array}$ & & 450 & 6.94 & 1094 & 657 & 8.58 \\
\hline 15 & s9 & 552011 & 8558164 & Drinking Water & Informal & 0 & 7.93 & 182 & 108 & 1.59 \\
\hline 16 & & & & $\begin{array}{c}\text { Dishwashing } \\
\text { Water }\end{array}$ & & 620 & 7.1 & 991 & 598 & 15.8 \\
\hline 17 & s10 & 552020 & 8558446 & Drinking Water & Informal & 0 & 7.58 & 176 & 105 & 1.69 \\
\hline 18 & & & & $\begin{array}{c}\text { Dishwashing } \\
\text { Water }\end{array}$ & & 340 & 7.62 & 184 & 110 & 3.24 \\
\hline 19 & s11 & 552026 & 8558448 & Drinking Water & Informal & 0 & 7.61 & 182 & 109 & 6.78 \\
\hline 20 & & & & $\begin{array}{l}\text { Dishwashing } \\
\text { Water }\end{array}$ & & 0 & 7.55 & 178 & 106 & 3.97 \\
\hline 21 & s12 & 552029 & 8558438 & Drinking Water & Informal & 0 & 7.71 & 179 & 108 & 3.83 \\
\hline 22 & & & & $\begin{array}{c}\text { Dishwashing } \\
\text { Water }\end{array}$ & & 0 & 7.7 & 180 & 109 & 5.93 \\
\hline 23 & s13 & 552034 & 8558430 & Drinking Water & Informal & 40 & 7.75 & 163 & 98 & 2.47 \\
\hline 24 & & & & $\begin{array}{c}\text { Dishwashing } \\
\text { Water }\end{array}$ & & 680 & 7.78 & 706 & 423 & 460 \\
\hline 25 & s14 & 551923 & 8558384 & Drinking Water & Informal & 0 & 7.64 & 178 & 107 & 2.06 \\
\hline 26 & & & & $\begin{array}{l}\text { Dishwashing } \\
\text { Water }\end{array}$ & & 0 & 7.56 & 177 & 106 & 1.98 \\
\hline 27 & s15 & 551934 & 8558396 & Drinking Water & Informal & 96 & 7.85 & 179 & 108 & 0.71 \\
\hline 28 & & & & $\begin{array}{l}\text { Dishwashing } \\
\text { Water }\end{array}$ & & 220 & 7.89 & 178 & 107 & 3.36 \\
\hline 29 & s16 & 551931 & 8558400 & Drinking Water & Informal & 0 & 7.66 & 175 & 105 & 1.24 \\
\hline 30 & & & & $\begin{array}{c}\text { Dishwashing } \\
\text { Water }\end{array}$ & & 180 & 7.81 & 184 & 111 & 2.09 \\
\hline 31 & s17 & 551945 & 8558416 & Drinking Water & Informal & 0 & 7.69 & 177 & 106 & 2.37 \\
\hline 32 & & & & $\begin{array}{c}\text { Dishwashing } \\
\text { Water }\end{array}$ & & 110 & 7.81 & 185 & 111 & 21.3 \\
\hline 33 & s18 & 551950 & 8558472 & Drinking Water & Informal & 0 & 7.73 & 181 & 109 & 0.59 \\
\hline 34 & & & & $\begin{array}{c}\text { Dishwashing } \\
\text { Water }\end{array}$ & & 88 & 7.01 & 178 & 107 & 14.4 \\
\hline 35 & s19 & 552202 & 8558582 & Drinking Water & Formal & 0 & 7.67 & 177 & 106 & 2.1 \\
\hline 36 & & & & $\begin{array}{l}\text { Dishwashing } \\
\text { Water }\end{array}$ & & 136 & 7.55 & 184 & 110 & 4.35 \\
\hline 37 & s21 & 551756 & 8558194 & Drinking Water & Formal & 0 & 7.49 & 175 & 105 & 0.68 \\
\hline 38 & & & & $\begin{array}{c}\text { Dishwashing } \\
\text { Water }\end{array}$ & & 0 & 7.72 & 76 & 45 & 0.59 \\
\hline
\end{tabular}




\begin{tabular}{|c|c|c|c|c|c|c|c|c|c|c|}
\hline 39 & s22 & 551903 & 8558050 & Drinking Water & Formal & 0 & 7.53 & 172 & 103 & 1.81 \\
\hline $\mathbf{4 0}$ & & & & $\begin{array}{c}\text { Dishwashing } \\
\text { Water }\end{array}$ & & 0 & 7.61 & 178 & 107 & 1.01 \\
\hline
\end{tabular}

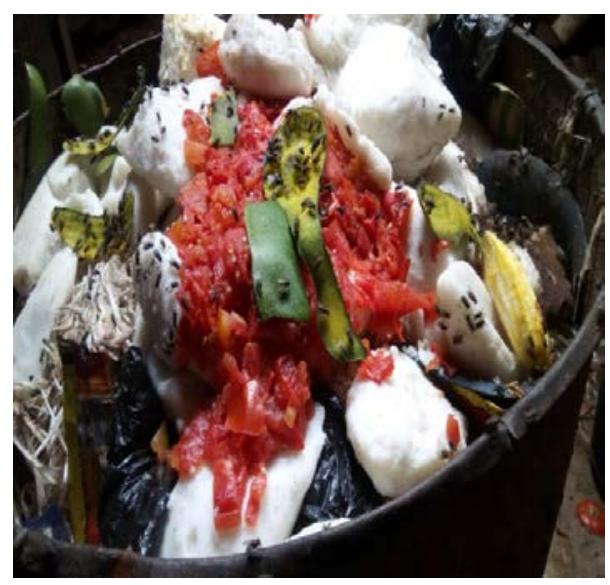

Figure 2. Garbage bin without a lid cover in kitchen at an informal food outlet (Photo: E. Chavura)

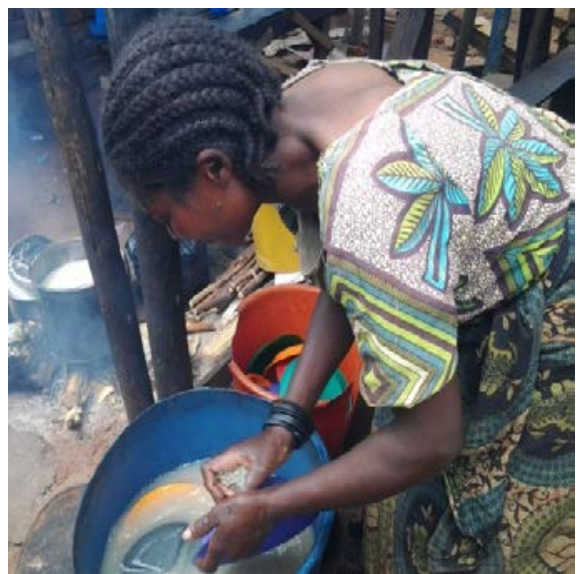

Figure 3. Visibly dirty water used for dish washing at a food outlet (Photo: E. Chavura

\section{References:}

1. Agensi, A., Tibyangye, J., Tamale, A., Agwu, E. and Amongi, C., 2019.Contamination potentials of Household Water Handling and Storage Practices in Kirundo Subcounty, Kisoro District, Uganda. Journal of Environmental and Public Health, 2019, pp.79321937932193.

2. Armah, F.A., 2014. Relationship between coliform bacteria and water chemistry in groundwater within gold mining environments in Ghana. Water Quality, Exposure and Health, 5(4): 183-195.

3. Asogwa, C.N., Ezenwajiaku, F.O., Okolo, C.A., Ekeh, F.N., Nwibo, D.D. and Chukwuka, C.O., 2015. Behavioural and biochemical responses of juvenile catfish (Clarias gariepinus) exposed to graded concentrations of cassava waste water. Animal Research International, 12(1): 2136-2147.

4. Busse, M. and Hefeker, C., 2007. Political risk, institutions and foreign direct investment. European Journal of Political Economy, 23(2): 397415.

5. Chiluwe, Q.W. and Nkhata, B., 2014. Analysis of water governance in Malawi: towards favourable enabling environment? Journal of water, sanitation and hygiene for development, 4(2), pp.313-323.

6. Cullet, $P, 2012$. Is water policy the new water law? Rethinking the place of law in water sector reforms. IDS Bulletin, 43(2), pp.69-78. 
7. Faruk, M.O. and Akhter, M.Z., 2011. Presence of coliforms and fecal coliforms in fast food items of local restaurants and fast food outlets of Dhakar city. Bangladesh journal of Microbiology, 28(1), pp.49-51.

8. Grigg, N.S., 2011. Water governance from ideals to effective strategies.Water International, 36(7), pp.799-811.

9. Gruber, J.S., Ercumen, A. and Colford Jr JM. Coliform bacteria as indicatorsof diarrheal risk in household drinking water: systematic review and meta-analysis. PloS one, 9(9), p.e107429.

10. Hanashiro, A., Morita, M., Matté, G.R., Matté, M.H. and Torres, E.A., 2005.Microbiological quality of selected street foods from a restricted area of São Paulo city, Brazil. Food Control,16(5): 439-444.

11. Jongh, L., 2015. Street vending in urban Malawi: Strategies and practices of vendors and local authorities. Available on http:www.rczi.org/wpcontent/uploads/2014/12/D2-Jongh.pdf. Accessed, 15,pp.11-16.

12. Kasungu Urban Socio-Economic profile, 1998. Kasungu District Council Data Base, Kasungu: Malawi Ministry of Local Government.

13. Kruy, S.L., Soares, J.L., Ping, S. and Sainte-Marie, F.F., 2001. Microbiological quality of ice, ice cream. sorbet sold on the streets of Phnom Penh; April 1996-April 1997. Bulletin de la Societe de pathologie exotique, 94(5): 411-414.

14. Leclerc, H.D.A.A., Mossel, D.A.A., Edberg, S.C. and Struijk, C.B., 2001.Advances in the bacteriology of the coliform group: their suitability as markers of microbial water safety. Annual Reviews in Microbiology, 55(1), pp.201-234.

15. Lee S.H., Kim S.J., 2002. Detection of infectious enteroviruses and adenoviruses in tap water in urban areas in Korea. Water Res. 36:24856.

16. Marobhe, N.J. and Sabai, S.M., 2016. Assessment of Food Safety Practices and Microbiological Quality of Street Vended Rice and Beans in Mlalakuwa Ward, Dar es Salaam. Journal of Chemical, Biological and Physical Sciences, 6(2): 297.

17. Malawi Bureau of Standards (MBS), 2005. Malawi Bureau of Standards Drinking Water Quality Specifications. MS 733: 2005.

18. Malawi Local Government (Market) By-Laws, 2015. Government of Malawi. Lilongwe: Government of Malawi.

19. Musa, O.I. and Akande, T.M., 2003. Food hygiene practices of food vendors in secondary schools in Ilorin. Niger Postgraduate Medical Journal, 10(3): 192-196.

20. Muzaffar, A.T., Huq, I. and Mallik, B.A., 2009. Entrepreneurs of the streets:an analytical work on the street food vendors of Dhaka city. International journal of Business and Management, 4(2): 80-84. 
21. National Environmental Health Policy, 2010. Government of Malawi. Lilongwe: Government of Malawi.

22. Neswiswi, A.B., 2014. Development of a Water Quality Index (WQI) for the Jukskei River Catchment, Johannesburg.

23. Nura, A.D. and Hamzaraj, E., 2016. Relationship between PhysicoChemical and Bacteriological Parameters in the Hydrosistem" Radoniqi" in Gjakova. Journal of International. Environmental Application and Science, 11(2): 207-212.

24. Nwachukwu CI, Otokunefor TV (2006). Bacteriolgical quality of drinking water supplies in the University of Port Harcourt, Nigeria. Nig. J. Microbiol. 20: 1383-1388.

25. Prabhu, P.M. and Shah, R.S., 2012. A study of food handlers in public food establishments in Maharashtra, India, 15(30): 3-51.

26. Saroj, S.D., Shashidhar, R., Dhokane, V., Hajare, S., Sharma, A. And Bandekar, J.R., 2006. Microbiological evaluation of sprouts marketed in Mumbai, India, and its suburbs. Journal of food protection, 69(10), pp.2515-2518.

27. U.S. Environmental Protection Agency, 2010. Microbial and disinfectionbyproducts rules: Microbials and disinfection byproducts. U.S.EPA, Office of Water. Retrieved November 25, 2010 from: http://water.epa.gov/lawsreg/rulesregs/sdwa/mdbp/index.cfm.

28. World Health Organization, 2008. Guidelines for drinking water quality:Incorporating the first and second addenda. Geneva: World Health Organization World Health Organization and UNICEF, 2006. Core questions on drinking water and sanitation for household surveys: Report of a Joint WHO/UNICEF Consultation, Rome, Italy.65(1): 416. 